\title{
Homelessness and public health
}

Homelessness is soaring, with serious health implications for those affected

Mark Fransham researcher, Danny Dorling Halford Mackinder professor of geography

School of Geography and the Environment, University of Oxford, Oxford, UK

The number of people officially recorded as sleeping on the streets of England rose from 1768 in 2010 to 4751 in autumn $2017 .^{1}$ Charities estimate the true figure to be more than double this. ${ }^{2}$ There has also been an increase in homeless families housed by local authorities in temporary accommodation, rising from 50000 in 2010 to 78000 in 2017.2 And in London alone there are an estimated 225000 "hidden homeless" people aged 16-25-arranging their own temporary accommodation with friends or family. 3 This rise in homelessness is not confined to the England but has affected most European countries. $^{4}$

\section{Health harms}

Homelessness harms health. The most common precursor, falling into arrears with housing payments, has a negative association with self-reported health comparable with that of unemployment. ${ }^{5}$ People living in damp, cold, or overcrowded housing experience greater physical risks to health, and strains on mental health occur though insecurity and personal debt. ${ }^{5}$ Associated health effects include respiratory conditions, depression, anxiety, unintentional injury, excess winter mortality, and skin irritation. ${ }^{6}$ At the extreme end, when last calculated (for 2001-09) single homeless people had an average age at death of 47 years, compared with 77 years for the general population. 7 
Homelessness can result from the loss of employment, substance addiction, poor mental or physical health, domestic abuse, relationship breakdown, or childhood trauma and neglect. The risk is higher for those leaving an institutional environment such as the military, psychiatric hospitals, the state care system, or prison. 8

\section{Causes of recent rise}

The recent rise in homelessness has its roots in welfare reform and the housing market. It is almost entirely accounted for by an increase in families losing their privately rented housing. Between 2010 and 2016 the number of households accepted as homeless by English local authorities rose by 16780 , from 42390 to 59260 ; the number becoming homeless because of losing a private sector tenancy rose by 12 600, from 6150 to 18 750 (fig 1).

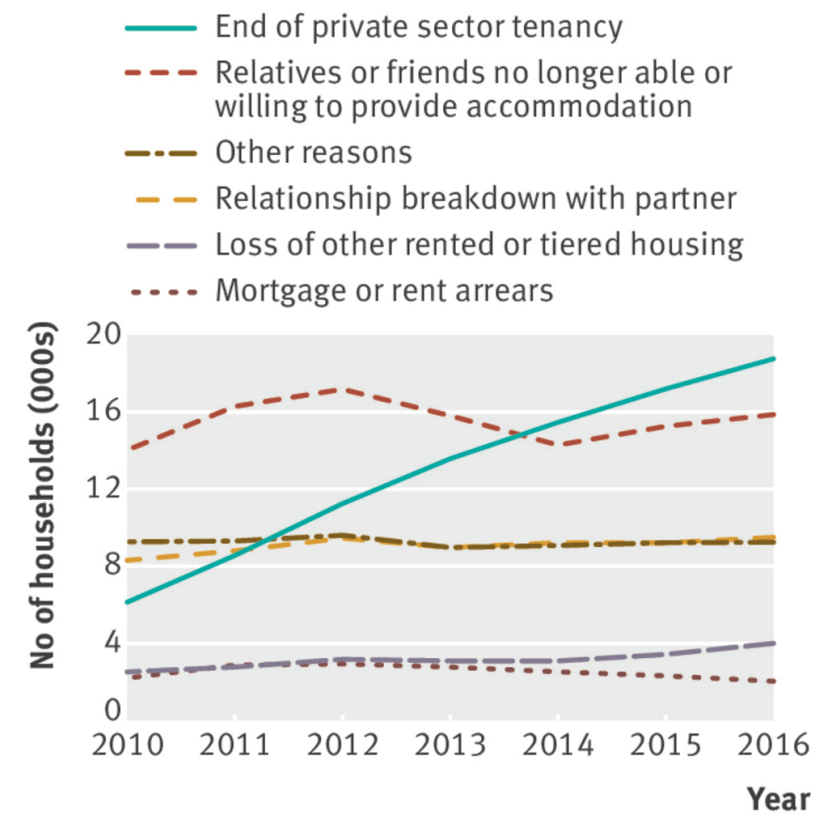

Fig 1 Reasons for losing last settled home among households English local authorities accepted as homeless and in priority need, England 2010-16 (Department for

Communities and Local Government, statutory homelessness statistics) 
Three likely causes are apparent. Firstly, since the early 1980s, housing has been increasingly unevenly distributed, ${ }^{9}$ causing upward pressure on market housing prices and overcrowding. The opposite had been the case from 1921 to 1981 . At the same time, reduced availability of social housing at truly affordable rent meant that, by 2016, as many poor families were living in private rented accommodation as in social rented housing. 10

Secondly, the rise in visible street homelessness is partly the result of reduced funding for single homeless hostels and support services. Austerity policies have meant that, since 2010, the funding available for supporting vulnerable people with their housing has been cut by $59 \%$ in real terms. ${ }^{11}$ Public services everywhere are under pressurehousing, health, domestic abuse, social care-and when they fail to provide the necessary support, homelessness can be the result.

Thirdly, welfare reforms have reduced the value of housing benefit paid to lower income families to subsidise housing costs. In 2011, housing benefit was restricted to the $30 \%$ cheapest properties in local areas. In 2013, a cap was introduced to limit the total benefits received by individual families, implemented by reducing the housing benefit paid. Rises in housing benefit were restricted to 1\% a year from 2014 and frozen in cash terms from April 2016, whereas rents have been increasing at $2 \%$ a year. This has shifted the financial risk of rising rents from the state to individual families on low incomes. The new working age benefit-universal credit-currently requires new claimants to wait for six weeks before receiving any support, though the government says that changes being implemented in February 2018 will reduce this waiting period. 


\section{Supporting homeless people}

What can be done to help those caught up in this crisis? Despite having more health needs, homeless people face barriers to accessing primary healthcare, leading to a higher rate of attendance at emergency departments. 8 This has prompted the development of some specialist primary healthcare services for homeless people, such as Oxford's Luther Street Medical Centre.

Support for rough sleepers has traditionally been based on a "treatment first" model, in which associated problems—-such as substance misuse and ill health-are tackled before stable housing is offered. The "housing first" model turns this on its head, offering a secure tenancy first, in recognition that other problems may be difficult to deal with while people are on the streets ${ }^{12}$. It has been given some of the credit for the success of Finland's strategy, the only European country where homelessness has fallen

recently. ${ }^{4} \mathrm{~A}$ feasibility study in Liverpool estimated potential annual savings of $€ 3 \mathrm{~m}$ $£ 5 \mathrm{~m}(€ 3 \mathrm{~m}-€ 6 \mathrm{~m} ; \$ 4 \mathrm{~m}-\$ 7 \mathrm{~m}){ }^{12}$ and housing first is now being piloted in Liverpool, Manchester, and Birmingham.

What is needed is a comprehensive strategy that improves support services for vulnerable people, an increased supply of affordable housing, more security of tenancies, adequate cash benefits to cover the rising cost of housing, and more efficient use of our existing housing stock.

\section{References}

1 Ministry of Housing, Communities, and Local Government. Rough sleeping statistics Autumn 2017, England. 2018. https://www.gov.uk/government/statistics/rough-sleeping- in-englandautumn-2017.

2 House of Commons Committee of Public Accounts. Homeless households: eleventh report of session 2017-2019. House of Commons, 2017.

3 London Assembly Housing Committee. Hidden homelessness in London. London Assembly, 2017. 
4 Fondation Abbe Pierre, FEANTSA. Second overview of housing exclusion in Europe. FEANTSA, 2017.

5 Clair A, Reeves A, Loopstra R, McKee M, Dorling D, Stuckler D. The impact of the housing crisis on self-reported health in Europe: multilevel longitudinal modelling of $27 \mathrm{EU}$ countries. Eur J Public Health 2016;26:788-93. doi:10.1093/eurpub/ckw071 pmid:27221606.

6 Thomson H, Thomas S, Sellstrom E, Petticrew M. Housing improvements for health and associated socio-economic outcomes: a systematic review. Campbell Collaboration, 2013.doi:10.4073/csr.2013.2.

7 Thomas B. Homelessness kills: an analysis of the mortality of homeless people in early twentyfirst century England. Crisis, 2012.

8 Fazel S, Geddes JR, Kushel M. The health of homeless people in high-income countries: descriptive epidemiology, health consequences, and clinical and policy recommendations. Lancet 2014;384:1529-40. doi:10.1016/S0140-6736(14)61132-6 pmid:25390578.

9 Tunstall B. Relative housing space inequality in England and Wales, and its recent rapid resurgence. Int J Housing Policy 2015;15:105-26. doi:10.1080/14616718.2014.984826.

10 Tinson A, Ayrton C, Barker K, Born TB, Aldridge H, Kenway P. Monitoring poverty and social exclusion 2016. Joseph Rowntree Foundation, 2016.

11 National Audit Office. Homelessness. National Audit Office, 2017.

12 Blood I, Copeman I, Goldup M, Pleace N, Bretherton J, Dulson S. Housing first feasibility study for the Liverpool city region . Crisis, 2017. 